\title{
Assigning the Roles and Responsibilities to Civil Engineering Freshers in Construction Industry
}

\author{
Vinod Bhuruk* ${ }^{1}$, Prof. O.R.S. Rao ${ }^{2}$ and Sayalee Gankar ${ }^{3}$ \\ ${ }^{1}$ Research Scholar, ICFAI Univeristy Jharkhand and Documentation Executive, National Institute of Construction \\ Management and Research (NICMAR), Pune, India. (Corresponding Author) \\ ${ }^{2}$ Professor and Vice Chancellor, ICFAI University Jharkhand, Ranchi, India. \\ ${ }^{3}$ Professor and Dean, Faculty of Management, MIT-World Peace University, Kothrud, Pune, India.
}

\begin{abstract}
The construction sector is a key driver of the overall development a country. The sector focuses on power, roads and bridges, dams and urban infrastructure. Government of India policies and plans aimed at improving the infrastructure, with specific focus on urban transformation (Smart City, Housing for all, etc.). This growth of the infrastructure sector offers job opportunities for Civil Engineering (CE) graduates. The construction Industry offers variety of job roles in different sectors. Construction industry requires application of skills and knowledge to perform duties in the planning, designing, and overseeing construction and maintenance of building structures, and facilities. Roads, railroads, airports, bridges, harbors, channels, dams, irrigation projects, pipelines, power plants, water and sewage systems, and waste disposal units are specific areas to fit for the jobs. Therefore, students enroll to civil engineering degree for build their career. The present paper focuses on civil engineering students' specific skills and how roles and responsibilities can be allocated to them. This paper also suggests initiatives to improve the skills and knowledge preferred by the Indian construction companies for the jobs.
\end{abstract}

Keywords: Skills; Competencies; Attributes; Fresh Civil engineering graduate; Roles; Responsibilities

\section{Introduction}

Stokes et al. (2013) defined employability skills as "the specific skills, attributes, behaviors, and characteristics considered necessary for individuals to attain and maintain employment as well as manage their careers, the concept of employability encompasses the extent to which people possess those skills, attributes, behaviors and characteristics to find and stay in the kind of work they want." Various issues in economy affect higher educated students to prefer their career Construction Industry (CI) due to fear of non-employable in other sectors. Therefore, they chose Civil Engineering (CE) discipline due to enormous job opportunities. Identified employability skills and its practical application on the job motivate students and improve confidence level for employability in multi-cultural environment. Therefore, capacity building further helps to become competent in developing competitive skills as perceived by the employer. Civil engineering discipline structure is designed to improve ability to apply the knowledge acquired in subject areas like, mathematics, basic sciences, engineering sciences, professional subjects and environmental issues. Further, Indian Civil Engineering Institute has focused strong foundation in theoretical/ experimental work to analyze, synthesize and design engineering products, processes and systems to competent for employability of students (AICTE, 2012).

Construction activities are project based and time constraints. Project delay leads huge loss to the project. Therefore, fresh civil engineers are responsible to assist managers in the functional area. Completion of training, civil engineering graduates roles are specified according to skills, knowledge and abilities based on performance judged. The roles and responsibilities include performing engineering analysis, design, plan, review and inspection. Imparted theoretical knowledge and practical skills like professional engineering concepts, principles, practices and methods utilized to efficiently handle engineering activities in complex work environment. Fresh civil engineering is expected to perform interpreting, analyzing and adapting methods, techniques and procedures to specific cases. Civil engineers are responsible to submit reports to their senior regarding review of completed work, technical soundness, 
appropriateness and compliance with standard engineering practices.

India's CI is expanding its investments in residential, infrastructure and energy projects towards sustainable growth. Changing trends in the global economy have enabled the requirement for flexibility, adaptability and innovation, which have led to specialized education and training demands in order to be a competitive (Ramdass, 2012).Student obtain higher grade in examinations has a better employment opportunities (Kulkarni and Chachadi, 2015).Therefore, the students are concentrating on theoretical approach than gaining skills more useful from career perspective. They lack awareness about specialization chosen and specific skill, knowledge and attribute required to perform a job. Selection of functional and career development requires understanding capabilities, knowledge and interest. Most of the students' views towards selection of specialization are from the perspective of job opportunities in the construction sector or high pay scale (Ratnayake and Butt, 2018). They lack information and awareness about current and future trends of the market. Student perception on employability is limited to academic grade and technical skills. This narrow perception is become an issues in their employability. Engineering knowledge and its application focused on teaching style which improve potential to accept the challenges while performing the job. Growing engineering institutes in India and quality of education to building competent students for employability remained an issue. Therefore, low employability is a problem in current scenario is due to lack of perceived skill and its application expected by the employer. Student's skills, knowledge, attributes, work systems, functions, processes are tested during interview whether fit for job. An employer does not expect fresh civil engineering students completing course to perform independently his/her job efficiently after joining. Therefore, it is ultimate responsibility of college/ institutes to aware students about job profile. RoleSpecific employability skills required are differs sectorwise. Awareness about job-specific role and responsibilities help students to choose a carrier.

Employability skills and competencies for the specific role are tested during the personal interview by the HR manager. Further, job performing capability is also judged by the questions raised and responses by the students. Student's selection for the job is long term investment by the company. Companies spend a lot of money on training of their fresh civil engineering graduates. Employer expectations and student's capability are matched for the specific role by looking at skills, knowledge and attribute (SNA). It is expected from the company recruited fresh civil engineering graduates has the competence to perform the assigned task as per their role. Civil engineering students expect opportunities in big companies. Getting placed in such companies, students 1should understand the basic criterion for interview. Apart from SNA, academic record is equally important. Each company has different criteria for shortlisting candidates for further evaluation (Jeswani, 2016).

Engineers play a vital role in the management of projects in a construction organization. According to Yorke and Knight (2006); Zaharim et. al. (2009), employability skills are the potential for obtaining and succeeding in graduate level. Civil engineering Course offered elective with specialized subjects. Selection of desired elective is required to understand its future current and future scope and trend along with interest. Guidance of faculty is crucial role in guidance for selection of elective understanding civil engineering student's abilities. Faculty member's knowledge, up-to date workplace requirements and employer's need helps in improve performance of civil engineering student. Managerial role taught and its application on the job through soft skills, such as leadership abilities and interpersonal skills aware to perform the complex tasks. Accordingly academic administration, institutional goals and vision aligned strengthen students' employability skills to help them compete in the market (Al-Alawneh, 2014). Good surveying firms prefer the civil engineer who can control cost alongwith various competencies required for the job (Olaniyiet. al., 2015). Students who want to become a design engineer are required to be competent in areas like roadway design, drainage design, land development, water management permitting (Anonymous, 2007).

Civil engineer students need to understand and develop professional responsibilities for compliance with regulatory requirement. Further, information about standard specifications which required testing and inspection of materials used for construction (Kahler and Kanapicki, 2012).The study Ajayi and Oyedele (2016) maps out competencies for designing out construction waste. The study suggests that five competency design task proficiency, low waste design skills, constructionrelated knowledge, behavioural competence and interprofessional collaborative competencies.

In the recent years, civil engineering education has developed rapidly and made the contribution to the modern engineering education system in India. Engineer's job role and responsibility involve a huge array of challenges within specific timeframes. Institutional, faculty member and student performance is correlated with employability. Institute relationship with industry has great impact on student employability (Ganiron Jr, and Ganiron 2012; Asojo, 2013). Inviting the industrial expert and sharing their knowledge and work experience about career path affects students about competencies, role, responsibilities, duties, etc. The ability to conceptualize a problem to identify the real 
problems and its solution is benefited to career advancement. It further expects the students to improve their core competencies to fit for the job. Developing solutions to the identified problems using appropriate technology, with limited resources (Blyth, 2016) is critical. It is an essential requirement, as projects involve many specialist skills and other skills for a successful completion. Therefore, ability to communicate ideas to subordinates as a team member affects smooth completion of the projects.

Faculty motivation plays a vital role in enhancing civil engineering student capabilities. Inclusion of theories, recent trends and approaches influence student performance management on the job. Further, knowledge about health, safety, environment, people management and legal aspects involved in study help students to aware duties and responsibilities. Inclusion case studies about effective planning and monitoring the process. Innovative teaching methods in engineering education combine theory, academic methods and professional practice. Using innovative didactic concepts in education is an excellent method to prepare students for job opportunities (Braun, 2013).A substantial percentage of civil engineers work at sites in different geographical areas. Apart from project execution, civil engineers has a job opportunities as administrative and supervisory positions with a variety of government and private employers. Civil engineers play a critical role in the heavy and civil engineering construction as a site investigation, feasibility studies, problem solving, cost estimates and construction scheduling. They provide innovative and cost-effective solutions to a variety of construction-related problems (Aurora, 2017).

During the course civil engineering students get the theoretical knowledge. Visionary approach towards face the problems on the job and overcome lacks. They are not well versed with the handle the situations in various situations. Therefore, awareness about understanding roles, responsibility, skills, and knowledge, attitude and company policies is important to perform on the job. Instead of focus on improving capabilities, civil engineering students accept the jobs due to fear of unemployment. Awareness about required capabilities, roles and responsibilities helps civil engineering students to obtain the jobs in career enhancement. Apart from soft skills, command over essential software knowledge and its application is helpful in decision making as well as smoothly work progress. This paper provides a roadmap for fresh civil engineering to understand core roles and responsibility for the particular job. Further, study provides guideline for students to become compatible and develop their competencies according to job requirement.

\section{Discussion}

\subsection{Civil engineering roles for fresh graduates}

\subsubsection{Design Engineer}

Design Engineer (DE) is an important opportunity for civil engineering students for career in the construction sector. DE should possess proficiency in design software essential for design field. civil engineering requires professional standards in both work performance and personal behavior/presentation. Further, civil engineering should have professionalism, strong ethics and confidentiality regarding business information, processes and products. He has to maintain integrity through open and honest interactions with colleagues and clients. Establishment and maintains effective relationships helps in gaining trust and respect among clients. Demonstrating quality outcomes carried out with quality in client meetings improves confidence about progress of activities in various phases. Communicating effectively and professionally with peers and managers helps in taking further accurate decisions so as to complete the project in stipulated timeframe (Cheal Consultants Ltd., 2012).

\subsubsection{Project Planner}

Planning engineers has a huge demand in construction industry. Knowledge and its application software are essential for design and planning field. The goal of planning is to minimize resource for cost effectiveness while satisfactorily completing the task. Efficient use of equipment, material, labor and ensuring coordinated effort for the project. The outcome of planning is predetermined course of action. The planning creates an orderly sequence of events, defines strategies to be followed in carrying forth the plan and describes ultimate disposition of the result. Putting the various activity of the project in the sequence on the time frame is the process of scheduling. Scheduling helps for continuous checking of the project (control) for resource mobilization, to minimize the cost and use of resources optimally. Several factors that civil engineers apply while planning include costs, maintenance and making sure the structure will including risk management. Geographical environment needs to be taken into account, anticipating natural disasters such as earthquakes as well as the stress of daily wear \& tear. Job profile is considered proper specifications and safety standards (Plancareer, 2016). Become a successful in the career, management of various activities related to planning is a crucial task.

The Table 1 shows the various roles designations, competencies and attribute expected by recruiters from fresh civil engineering graduates. It may be seen that recruiters look for not only technical knowledge and hands-on skills in civil engineering and IT skills but also 
soft skills like verbal and written communication, team work, leadership skills etc.

Table 1: Competencies expected by Recruiters of Fresh Civil Engineering graduates

\begin{tabular}{|c|c|c|c|}
\hline $\begin{array}{l}\text { Name of the } \\
\text { Company/ } \\
\text { Recruiter }\end{array}$ & Job Designation & Competencies & Attribute \\
\hline \multirow{4}{*}{$L \& T$} & \multirow{4}{*}{$\begin{array}{l}\text { Site Engineer, } \\
\text { Surveyor, Junior } \\
\text { Engineer }\end{array}$} & $\begin{array}{l}\text { More than } 60 \% \text { Marks in overall Graduation without any } \\
\text { backlogs and remarks }\end{array}$ & \\
\hline & & Ability to do work with any inconvenience & Flexibility, Commitment \\
\hline & & Responsible and analysis with his team members & Team Work \\
\hline & & Leadership quality skills to maintain his team & Team Management \\
\hline \multirow{5}{*}{$\begin{array}{l}\text { Hindustan } \\
\text { Construction } \\
\text { Company (HCC) }\end{array}$} & \multirow{5}{*}{ Site Engineer } & Self-motivated, innovative, hardworking and able to use & Logical Thinking, Smart \\
\hline & & $\begin{array}{l}\text { Conversant with all aspects of Civil practice and procedure } \\
\text { Extensive knowledge }\end{array}$ & $\begin{array}{l}\text { Engineering } \\
\text { Fundamentals and }\end{array}$ \\
\hline & & Effective and result-orientated management skills & $\begin{array}{l}\text { Commitment, Team } \\
\text { Management }\end{array}$ \\
\hline & & Ready to work under pressure and deliver results. & Flexibility \\
\hline & & Self-motivated and Team Player & Team Management \\
\hline \multirow{7}{*}{$\begin{array}{l}\text { PROBASE } \\
\text { Manufacturing }\end{array}$} & \multirow{7}{*}{ Site Engineer } & $\begin{array}{l}\text { Manage the road construction project to ensure that the } \\
\text { works are executed in accordance to the contracted }\end{array}$ & $\begin{array}{l}\text { Logical Thinking, } \\
\text { Proficiency Standards }\end{array}$ \\
\hline & & $\begin{array}{l}\text { Day to day management of site, including managing and } \\
\text { monitoring the site workforce and their work performances }\end{array}$ & Approachability \\
\hline & & $\begin{array}{l}\text { Conduct daily line balancing to ensure optimal headcount } \\
\text { and utilization of materials and machines }\end{array}$ & Engineering Practice \\
\hline & & Ensure that all materials used and work performed are as per & Specifications and \\
\hline & & $\begin{array}{l}\text { Liaise with customer with regards to job progress and job } \\
\text { inspection and following up with work certification }\end{array}$ & $\begin{array}{l}\text { Written Communication } \\
\text { Skills, Verbal } \\
\text { Communication Skills }\end{array}$ \\
\hline & & $\begin{array}{l}\text { Provide the necessary guidance and training to the local } \\
\text { workforce and sub-contractor with the requisite knowledge }\end{array}$ & Team building \\
\hline & & $\begin{array}{l}\text { Submit weekly and monthly costs data for management } \\
\text { accounting purposes and project performance reports for }\end{array}$ & $\begin{array}{l}\text { Written Communication } \\
\text { Skills, Presentation }\end{array}$ \\
\hline \multirow{8}{*}{ Hrsolution } & \multirow{8}{*}{ Site Engineer } & Responsible for execution with quality of work & $\begin{array}{l}\text { Quality Management } \\
\text { Skills }\end{array}$ \\
\hline & & Responsible for progress of work at site & \\
\hline & & Responsible for safety \& quality & Safety and Quality Audit \\
\hline & & Responsible for maintaining records & Computer Proficiency \\
\hline & & Good commanding power & Leadership \\
\hline & & Handled a team of Foreman / Supervisor & Team Management \\
\hline & & Smart in managing contractors / workers & Communication Skill \\
\hline & & $\begin{array}{l}\text { Willing to work from basic design to advanced, Innovate } \\
\text { bent of mind, Analytical and Problem solving skills }\end{array}$ & \\
\hline
\end{tabular}




\begin{tabular}{|c|c|c|c|}
\hline \multirow{9}{*}{ Skill Groomers } & \multirow{9}{*}{ Jr. Engineer } & Checking Center-line of RCC Work & Testing Practices \\
\hline & & Checking reinforcement as per RCC drawings & \\
\hline & & Responsible for progress of work along with quality control & Design Skills \\
\hline & & Effective technical supervision on all concrete work & $\begin{array}{l}\text { Emotional balance, self- } \\
\text { control, Specifications } \\
\text { and Inspection Standards }\end{array}$ \\
\hline & & Making indents for the materials required at site & $\begin{array}{l}\text { Written Communication } \\
\text { Skills, Computer } \\
\text { Proficiency, Probability } \\
\text { and Statistics }\end{array}$ \\
\hline & & Maintaining records of daily work progress at site & Computer Proficiency \\
\hline & & $\begin{array}{l}\text { Daily reporting to line manager for all works executed at } \\
\text { site }\end{array}$ & $\begin{array}{l}\text { Written Communication } \\
\text { Skills, Presentation } \\
\text { Skills }\end{array}$ \\
\hline & & $\begin{array}{l}\text { Preparing Bar Bending Schedule (BBS) as per structural } \\
\text { drawings }\end{array}$ & \\
\hline & & $\begin{array}{l}\text { Preparing \& checking of bills as per work order } \& \text { actual } \\
\text { work }\end{array}$ & \\
\hline \multirow{3}{*}{$\begin{array}{l}\text { Asia (Chennai) } \\
\text { Company } \\
\text { Engineering Pvt. } \\
\text { Ltd. }\end{array}$} & \multirow{3}{*}{ Junior Engineer } & Responsible for Computing Quantities & Computer Proficiency \\
\hline & & $\begin{array}{l}\text { Supervising works by controlling Labour\& Material to } \\
\text { maintain quality and to maintain Daily labour report }\end{array}$ & $\begin{array}{l}\text { Computer Proficiency, } \\
\text { Probability and } \\
\text { Statistics, } \\
\text { Communication Skill }\end{array}$ \\
\hline & & Daily Progress report and other day to day reports on work & $\begin{array}{l}\text { Computer Proficiency, } \\
\text { Commitment, } \\
\text { Presentation Skills }\end{array}$ \\
\hline \multirow{3}{*}{$\begin{array}{l}\text { Nagarjuna } \\
\text { Construction } \\
\text { Company Limited }\end{array}$} & \multirow{3}{*}{ Design Engineer } & Exposure to design software like Staad-pro \&Autocad & Design Skills \\
\hline & & Preferably candidates who can speak English and Telugu & $\begin{array}{l}\text { Verbal Communication } \\
\text { Skills }\end{array}$ \\
\hline & & Hard working with good communications & $\begin{array}{l}\text { Verbal Communication } \\
\text { Skill, Tolerance }\end{array}$ \\
\hline \multirow{5}{*}{ Cyient Ltd. } & \multirow{5}{*}{$\begin{array}{l}\text { Senior Design } \\
\text { Engineer }\end{array}$} & Design, Modeling and detailing using Creo & Design Skills \\
\hline & & $\begin{array}{l}\text { Interaction with project team internally and customer during } \\
\text { CAD Project execution }\end{array}$ & $\begin{array}{l}\text { Team Work, } \\
\text { Presentation Skills }\end{array}$ \\
\hline & & Analyze and apply GD\&T to components & \\
\hline & & $\begin{array}{l}\text { Check in /check out - parts and assemblies from PDM data } \\
\text { base }\end{array}$ & $\begin{array}{l}\text { Specifications and } \\
\text { Inspection Standards }\end{array}$ \\
\hline & & $\begin{array}{l}\text { Handle the task independently with little or no support from } \\
\text { lead }\end{array}$ & Reliability \\
\hline \multirow{4}{*}{$\begin{array}{l}\text { Mahindra Logistics } \\
\text { Ltd. }\end{array}$} & \multirow{4}{*}{ Site Lead-Civil } & $\begin{array}{l}\text { On-site supervision of all civil \& structure work at project } \\
\text { site }\end{array}$ & $\begin{array}{l}\text { Commitment, } \\
\text { Engineering Practice }\end{array}$ \\
\hline & & Controlling project schedule and budget & $\begin{array}{l}\text { Design Skills, } \\
\text { Accounting Skills }\end{array}$ \\
\hline & & $\begin{array}{l}\text { Preparation of periodic project progress report giving } \\
\text { updates on budget, schedule (comparison between approved } \\
\text { schedule / budget with likely schedule / budget with reasons } \\
\text { for deviation and action plan to catch with the initial } \\
\text { schedule / budget) }\end{array}$ & $\begin{array}{l}\text { Written Communication } \\
\text { Skills, Presentation } \\
\text { Skills }\end{array}$ \\
\hline & & $\begin{array}{l}\text { Updating project budget and schedule in project } \\
\text { management software }\end{array}$ & $\begin{array}{l}\text { Accounting Skills, } \\
\text { Design Skills }\end{array}$ \\
\hline
\end{tabular}




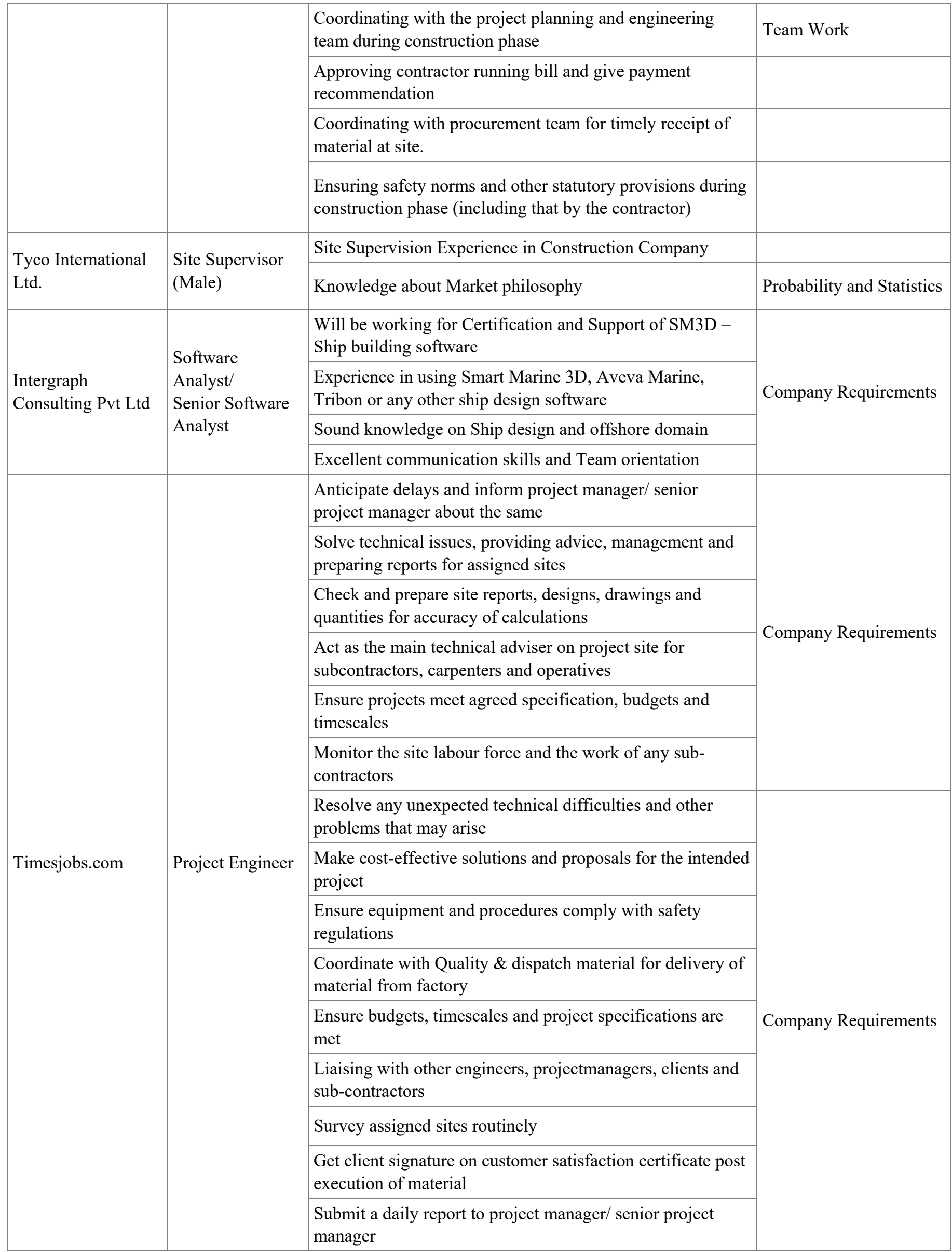

Source : Compiled by the authors, 2017

An analysis of the technical skills expected by the recruiters shows that the skills depend on the role that is assigned to the candidate. Table 2 captures role wise technical skill requirements. The following requirements are for the positions posted specifically. These are various requirements for the performing role. 


\section{Design Engineer}

- $\quad$ Conducting preliminary engineering studies.

- $\quad$ Assessment of project needs, conducts engineering design and plant or system performance review, reviews engineering documents, and provides guidance to management on project requirements.

- $\quad$ Ability to identify, formulate and solve engineering problems.

- Application problem solving approaches, such as brainstorming, fishbone diagramming, and engineering theory to electric system projects.

- Determining the specifications for the solution and develops conceptual design for new facilities, collaborates with others to reach consensus, and issues engineering documents to initiate design and construction.

- $\quad$ Reviews, evaluation and implementation of new technologies that support best practices in areas that include, but are not limited to work management, outage restoration, and the planning and scheduling of work.

- Use of logical thought processes to analyze information and draw conclusions.

- Identifying inconsistent or missing information.

- $\quad$ Ability to design and conduct experiments, as well as to analyze and interpret data.

- Tests possible hypotheses to ensure the problem is correctly diagnosed and the best solution is found.

- $\quad$ Reading and interpreting Process and Instrumentation Drawings.

- $\quad$ Preparation, reading and interpreting blue prints and one line diagrams.

- Using draft instruments, engineering and mathematical references and tables, charts, computer equipment, accepted documentation processes required to perform professional engineering studies, calculations, analysis, estimates, etc.

- Interpreting and condenses field notes to prepare and/or oversee the preparation of plans, maps and drawings.

- $\quad$ Maintaining accurate filing and records system for projects from initiation to project close out.

- $\quad$ Operates various computer aided engineering design, analysis programs and tools

- $\quad$ Understands, applies and maintains compliance with regulatory and industry standards and requirements.

\section{Project Planning}

- $\quad$ Determining project requirements and estimates resources.

- $\quad$ Conducting economic analyses to determine optimum plan.

- $\quad$ Creating an effective project plan (Prioritize tasks and Create milestones).

- $\quad$ Anticipating in project constraints and creating alternative plans.

- $\quad$ Monitoring project status against the plan and reports on the results.

- $\quad$ Providing input for requests for proposals and assisting in the analysis of responses.

- $\quad$ Providing input into the preparation of contracts and participating in the negotiation of revisions, changes and additions to contractual agreements with architects, consultants, clients, suppliers and subcontractors.

- $\quad$ Performing contract administration and construction inspections for minor projects.

- $\quad$ Preparing and submits budget estimates and progress and cost tracking reports.

- Acts independently on technical matters in the assigned field of expertise and recommends approval of professional services, materials \& construction procurement contracts.

- $\quad$ Ensuring correct material is available and expedited for the construction of the project.

- $\quad$ Conducting repair versus replace analysis on equipment. 
- $\quad$ Conducting lease versus buy analysis for project equipment.

- $\quad$ Conducting labour analyses to determine run/don’t run decision making.

\section{Construction}

- $\quad$ Ensuring external data and drawings are approved in accordance with agreed procedures and schedules

- Interpreting and explaining plans and contract terms to administrative staff, workers, and clients.

- $\quad$ Supports the licensing activities and safety assessment related functions in close collaboration with the safety group.

- $\quad$ Taking actions to deal with the results of delays, bad weather, or emergencies at construction site.

- $\quad$ Taking actions to deal with the results of delays, bad weather, or emergencies at construction site.

- $\quad$ Studies job specifications to determine appropriate construction methods.

- $\quad$ Ensures all appropriate permitting is obtained.

\section{System Operation, Maintenance and Repair}

- Designs tests for and assists in the investigation of relaying and control scheme problems.

- $\quad$ Develops and implements manual and automated test plans for equipment.

- $\quad$ Prepares load analysis for distribution substations and develop remediation plan for substations that warrant corrective action.

- $\quad$ Develops operating information which serves as a knowledge base for responding to various contingency conditions on the power delivery system.

- $\quad$ Evaluates, prepares and recommends distribution system protection coordination schemes and conduct fault studies for the proper application of fuses, reclosers and substation relay settings.

- Conducts engineering analysis and develops recommendations to maintain and improve plant and system efficiency, reliability, safety, environmental compliance and cost performance.

- Implements programs to maintain facility assets in the most efficient and effective manner in order to meet or exceed asset life expectancy.

- $\quad$ Performs engineering studies and Root Cause Analysis to predict plant/system equipment performance.

- Identifies defects and failure modes, assesses current operating practices, determines cost benefit analysis on equipment deficiencies and then develops modifications to current configuration that will improve overall performance.

- $\quad$ Develops integrated performance system for effective monitoring and optimization of units and systems.

- $\quad$ Conducts all activities in compliance with applicable environmental, fire and safety laws, codes and directives.

- Understands the requirements of other disciplines, electrical engineering, mechanical engineering, civil engineering.

\section{Other Roles}

- Understanding and application of the information technology required for distributed control, communications and automation components of Smart Grid.

- Is able to seamlessly integrate new technologies with legacy technologies without compromising safety or reliability.

- Understands legislative and regulatory functions and their impact on the design and construction of new plant or rebuild of existing plant.

- $\quad$ Collaborates in the development of industry standards such as NERC reliability, compliance development strategies, etc.

- Applies a basic understanding of finance and engineering economics.

- Is able to clearly and effectively communicate with corporate managers, end customers and engineers from other departments.

- Understands the basics of systems engineering, IT fundamentals, communications systems basics to help bridge the gaps across disciplines to avoid engineering re-designs. 


\section{Site Engineer}

- $\quad$ Organizing work and checking in accordance with the drawings and specification.

- $\quad$ Liaising with the project planning engineer regarding construction programmes.

- $\quad$ Checking materials and work in progress for compliance with the specified requirements.

- $\quad$ Observance of safety requirements.

- $\quad$ Resolving technical issues with employer's representatives, suppliers, sub-contractors and statutory authorities.

- Quality control in accordance with CSIs/procedures method statements, quality plans and inspection and test plans, all prepared by the project management team and by subcontractors.

- $\quad$ Liaising with clients, subcontractors and other professional staff, especially quantity surveyors and the overall project manager.

- $\quad$ Supervising and counseling junior or trainee engineers.

- Measurement and valuation (in collaboration with the project quantity surveyor where appropriate).

- $\quad$ Providing data in respect of variation orders and site instructions.

- $\quad$ Preparing record drawings, technical reports, site diary.

- Job review of subordinate staff.

Source :Compiled by Authors (Engineering Competencies, 2018; www.quora.com, 2018; https://theconstructor.org, 2018; https:// theconstructor.org, 2017)

\subsection{Skill enhancement vs. Job profile}

Skills along with consistently good academic record are extremely important for employability in today's highly competitive business environment. Engineering education and technical skills are two fundamental requirements to be possessed by graduates. Nontechnical and intangible skills help students to perform their duties during job in the company. Connecting students with employers helps to inspire students into considering the wide range of job roles available across a wide range of disciplines by meeting role models who are actively working within those sectors (Koch, 2015). Jobs varying from planning, implementation and designing involved structural activities are available for civil engineers after graduation. Civil engineering students seeking employment are fit for skill and knowledge but their attributes also from employer perspective. Various construction companies have adopted use of standardized assessment criteria irrespective of college tier, location and reputation. Focus on factors affecting student's professional development during the engineering courses during workplace learning required to aligned. Obtaining a civil engineer degree is a learning and application phase. Theoretical learning understands concept where practical, site and industrial visits aware application of learned concepts (Ratnayake, Butt \& Budge, 2009; Butt, Ratnayake \& Budge, 2016). Case study method demonstrates situations while performing job, situations arises time to time and application with analytical thinking by the manager to tackle comes through observation. Civil engineering faculty member focuses on aware student recent about trends and concept. It further helps in divert student mind, change the idea to cultivate high quality talents to possess solid foundation, innovative thinking and practice ability (Wang and $\mathrm{Hu}, 2012$ ).

\subsection{Career opportunities for civil engineering students}

Construction industry is globally booming sector. In India Construction sector is the second largest sector. Projects such as creation of smart cities, and greater allocation to roads, irrigation and water projects shall boost infrastructure investments. Civil engineers have a lot of job opportunities in upcoming infrastructure projects (Refer Fig. 1). Construction industry faces a massive shortfall of qualified engineers to support for completion of infrastructure projects. This study aims at contributing to identify engineering education as well as provide roadmap to educational practice in higher engineering education. Focus on student's professional development awareness during the engineering courses and more specifically during workplace learning affects significantly. There are various categories in the field of engineering. Civil engineers are required for planning structures like buildings, roads, highways, bridges, tunnels, airports, dams, subways, harbors and water and waste treatment system and plants. Broad discipline areas in civil engineering have good demand include environmental, structural, hydraulics, construction, sanitary, transportation and soil mechanics. 


\begin{tabular}{|c|c|c|}
\hline \multirow{3}{*}{$\frac{\downarrow}{\text { Knowledge }}$} & Employability Skills & \multirow{3}{*}{$\frac{7}{\text { Attribute }}$} \\
\hline & 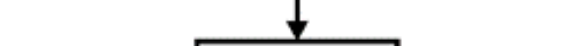 & \\
\hline & Skills & \\
\hline $\begin{array}{l}\text { - Engineering and } \\
\text { Technology } \\
\text { - Building and Construction } \\
\text { - Knowledge of Computer } \\
\text { and Softwares } \\
\text { - Mathematics } \\
\text { - Design } \\
\text { - English Language } \\
\text { - Administration and } \\
\text { Management } \\
\text { - Physics and Chemistry } \\
\text { - Law and Government } \\
\text { - Customer and Personal } \\
\text { - Service } \\
\text { - Economics and Accounting } \\
\text { - Computers and Electronics } \\
\text { - Personnel and Human } \\
\text { Resources } \\
\text { - Public Safety and Security } \\
\text { - Sales and Marketing } \\
\text { - Education and Training } \\
\text { - Transportation } \\
\text { - Psychology } \\
\text { - Clerical }\end{array}$ & $\begin{array}{l}\text { - Reading Comprehension } \\
\text { - Critical Thinking } \\
\text { - Active Listening } \\
\text { - Speaking } \\
\text { - Complex Problem Solving } \\
\text { - Operations Analysis } \\
\text { - Systems Analysis } \\
\text { - Time Management } \\
\text { - Science } \\
\text { - Active Learning } \\
\text { - Systems Evaluation } \\
\text { - Judgment and Decision } \\
\text { Making } \\
\text { - Coordination } \\
\text { - Monitoring } \\
\text { - Social Perceptiveness } \\
\text { - Learning Strategies } \\
\text { - Writing } \\
\text { - Persuasion } \\
\text { - Instructing } \\
\text { - Management of Material } \\
\text { - Resources } \\
\text { - Management of Material } \\
\text { - Mesources } \\
\text { - } \text { Resources } \\
\text { - Management of Personnel } \\
\text { Resources }\end{array}$ & $\begin{array}{l}\text { - Integrity } \\
\text { - Flexibility } \\
\text { - Analytical Thinking } \\
\text { - Reliability } \\
\text { - Attention } \\
\text { - Initiative } \\
\text { - Achievement/Effort } \\
\text { - Team work } \\
\text { - Willingness to learn } \\
\text { - Self discipline } \\
\text { - Professional } \\
\text { Commitment to high } \\
\text { - standards } \\
\text { - Self motivated } \\
\text { - Empathy } \\
\text { - Stress Tolerance }\end{array}$ \\
\hline
\end{tabular}

Figure 1: Classification of Employability Skill 


\section{Conclusion}

There are various career opportunities in construction industry for fresh Civil Engineering graduates. However each role requires different skills and aptitude on the part of the students. Most of the graduating students are not aware of this. They have a mistaken perception that securing good marks/ grade in examinations is enough to get a good job. Engineering Colleges need to take the responsibility to build awareness among the students with regard to the career opportunities In the construction industry, particularly various roles, responsibilities and the skills needed to perform such roles effectively. Further, the graduating students should be equipped with those skills. This alone may bridge the skill gap and enhance the employability of the graduating students.

\section{References}

AICTE. (2012). Retrieve from $:<$ http://www.aicteindia.org/downloads/MODEL_SYLLABI_FOR_UG_Civil_Engg.pdf $>$. [Accessed : August 28 2016].

Al-Alawneh, M. K. (2014). Measuring Students' Employability Skills as they are perceived at Yarmouk University. Canadian Social Science. Vol. 10, No. 1, pp. 10-20.

Blyth, R. (2016). A look at the future of engineering in South Africa: Part 1.Civil Engineering, pp. 37-41.

Braun, B. O. (2013). Innovative Methods in Engineering Education. CAETS 2013, Budapest.

Butt, A., Ratnayake, R., \& Budge, T. (2016). Planning education and inter-cultural collaboration: awareness, innovation, reflection and preparation for practice. Bhumi, The Planning Research Journal, 3(1).

Engineering Competencies. <http://www.cewd.org/Documents/EngCompModel.pdf $>$. [Accessed on 15 January 2018].

Jain, A. What type of work does a fresher civil engineer do?

Blog. Retrieve from: <https://www.quora.com/What-type-of-work-does-a-fresher-civil-engineer-do>. [Accessed on 2 June 2017].

Jeswani, S. (2016). Assessment of Employability Skills among Fresh Engineering Graduates: A Structural Equation Modeling Approach. The IUP Journal of Soft Skills, Vol. X, No. 2, pp. 8-43.

Knight, P. T. \& Yorke, M. (2006). Embedding employability into the curriculum learning and employability (series 1). York: The Higher Education Academy.

Kulkarni, N. \&Chachadi, A. H. (2015). Self Efficacy Beliefs and CampusPlacement Outcome. SCMS Journal of Indian Management. Vol. XII, No. 3, pp. 104-119.

Ramdass, K. (2012). Programme re-curriculation: an experience at the university of Johannesburg. International Journal of Business and Social Science, Vol. 3 No. 8, pp. 204-36.

Roles and Responsibility of Site Engineer. (2017). <https://theconstructor.org/construction/civil-site-engineer-rolesresponsibilities/18446/>. [Accessed on January 10 2018].

Stokes, C. L., Closson, R. B. \& Young, W. (2013). A Case Study Understanding Employability Through the Lens of Human Resource Executives.

The Constructor. (2018). Retrieve from: <https://theconstructor.org/construction/civil-site-engineer-roles-responsibilities/18446/ >. [Accessed on 3 January 2018]

Wang, X and Hu, Q. (2012). Research into the improvement of College Students' Life-Long Learning Ability. Creative EducationSupplement: 2012 world Congress on Engineering and Technology. Scientific Research. pp. 76-80.

Zaharim, A., Yusoff, Y., Omar, M.Z., Mohamed, A. and Muhamad, N. (2009). Engineering employability skills required by employers in Asia. In Proceedings of the 6th WSEAS International Conference on Engineering Education. pp. 195-201.

Koch, G. (2015). Connect Students to Employers. Seen Managzine. Retrieve from: <http://www.seenmagazine.us/Articles/ Article-Detail/ArticleId/5060/CONNECT-STUDENTS-TO-EMPLOYERS $>$. [Accessed on 12 January 2018].

Olaniyi, A, I., Adewumi, A. O. and Timothy, I, O. (2015). Analysis of Projects undertakenby Quantity Surveyors in Lagos State, Nigeria. Organization, Technology and Management in Construction - An International Journal. Vol. 7, No. 1, pp, 1209 - 1216 Anonymous. (2007). Positions. Institute of Transportation Engineers. ITE Journal.Vol. 77, No. 8, p. 51

Ganiron Jr, T. U. and Ganiton, T. M. (2012). Social Capital on Civil Engineer Career Success. International Journal of Innovation, Management and Technology. Vol. 3, No. 6, pp. 718-724.

Kahler, D. and Kanapicki, C.(2012). Civil Engineering Responsibilities in Special

Inspection. Presented in: The ASCE Joint Conference of the Texas Section and the Construction Institute, November 9, 2012. Asojo, A, O. (2013). Connecting Academia with Industry: Pedagogical experiences from a collaborative design project. Asia Pacific International Conference on Environment-Behaviour Studies on"From Research to Practice", Organised by University of Westminster, London, UK, 4-6 September 2013. 
Ajayi, S, O. and Oyedele, L. O. (2016). ompetency-based measures for designing out construction waste:task and contextual attributes. Engineering, Construction and A rchitectural Management. Vol. 23 No. 4, pp. 464-490.

Aurora, N. (2017). Blog: The Role of Civil Engineers in the Construction Industry. Retrieve from <https:// www.constructioncrossing.com/article/480003/The-Role-of-Civil-Engineers-in-the-Construction-Industry/>. [Accessed on 17 November 2017].

Ratnayake, R. and Butt, A. (2018). Encounters with the unfamiliar: international planning education. International Planning Studies. Vol. 23, No. 1, pp. 51-64.

Ratnayake, R. G., Butt, A., \& Budge, T. M. (2009). Cross-Cultural Learning from the Tsunami: Professional Planners from Australia and Sri Lanka. 